\title{
Rock-Cut Church Göreme 31 (Cappadocia, Turkey): New Data from the Study in Situ (2014-2015)
}

\author{
Danil Shevchenko | ORCID: 0000-0002-9018-7280 \\ Shenyang Normal University, Shenyang, China \\ shevchenko.danilig79@gmail.com \\ Yulia Sadovskaya | ORCID: 0000-0002-8720-3446 \\ Independent researcher, Saint Petersburg, Russia \\ jusadvsk@gmail.com \\ Vladimir Shkondin \\ Independent researcher, Fethiye, Turkey \\ v.shkondin@gmail.com
}

Yegor Zhurbin

Independent researcher, Saint Petersburg, Russia

egor.zhurbin@gmail.com

Alexey Ostrovsky | oRcID: 0000-0002-4350-9638

Independent researcher, Tbilisi, Georgia

satai@akauri.com

\begin{abstract}
This paper presents new findings from our study in situ of a small Christian church, known as Göreme 31, which is situated above the Kılıçlar church in Göreme (Cappadocia, Turkey). It was discovered and briefly described at the beginning of the 2oth century, but after that almost no additional information was published. We were able to study Göreme 31 in situ in 2014-2015. In this article, we present new findings and updated information on this church: data on three previously unpublished murals in the naos, corrections to the readings of the frescoes of St. Auxentius (previously identified as St. Vincent), St. Sisinius (previously identified as St. Irene), and St. George with St. Theodore, and discussion of the enigmatic tiny grave in the funeral chamber.
\end{abstract}




\section{Keywords}

Göreme31-Cappadocia-churches-rock-cutchurches-frescoes-epigraphics-graves

\section{Introduction}

The earliest Christian communities, escaping from the persecution of the Roman authorities, came to Cappadocia probably in the first centuries CE. They had changed the natural landscape of that territory and carved multiple temples, dwellings, stables, refectories, and wineries in existed tufa deposits. For many centuries Cappadocia was one of the most significant centers of the Christian world, retaining this status even in the periods of the Arab invasions and the Ottoman conquest. According to R. G. Ousterhout, more than seven hundred churches have been counted in the region; many of them preserve fresco decorations. ${ }^{1}$ Unfortunately, the majority of frescoes were destroyed or badly damaged in the Seljuk and Ottoman eras, and then again in the 19th2oth centuries, when churches and chapels were transformed into dovecotes and different outbuildings by local peasants. Therefore, any remaining cult object with relatively well-preserved wall paintings has cultural value and scientific significance.

Göreme 31 is a small Christian church, cut in the conical rock located left atop of the well-known rock-cut column Kılıçlar Kilise (the Swords Church, also known as Göreme 29) (Fig. 1). ${ }^{2}$ It was first mentioned by the French epigrapher and Byzantinist Guillaume de Jerphanion at the beginning of the 2 oth century. ${ }^{3}$ He identified Göreme 31 as a chapel near the Kılıçlar church and published

1 R. Ousterhout, A Byzantine settlement in Cappadocia, Washington D.C., 2005 (Dumbarton Oaks Studies, 42), p. 7 .

2 L. Rodley, Cave monasteries of Byzantine Cappadocia, Cambridge, New York, 1985 (reprinted 2010), pp. 42-45.

3 Results of Jerphanion's researches in Cappadocia were published in G. Jerphanion, Une nouvelle province de l'art Byzantin : Les églises rupestres de Cappadoce, ...

- ... Texte, Tome premier (première partie), Paris, 1925.

- ... Planches, Premier album, Paris, 1925.

- ... Planches, Deuxième album, Paris, 1928.

- ... Texte, Tome premier (deuxième partie), Paris, 1932.

- ... Planches, Troisième album, Paris, 1934.

- ... Texte, Tome deuxième (première partie), Paris, 1936.

- ... Texte, Tome deuxième (deuxième partie), Paris, 1942.

Further, for short, we refer to these volumes as to GJ Texte I.1, GJ Planches I, GJ Planches II, GJ Texte I.2, GJ Planches III, GJ Texte II.1, and GJ Texte II.2 (respectively). 
a brief description with one drawing and two photos of the paintings of the vault. ${ }^{4}$ In the early 2000-s, Catherine Jolivet-Lévy published her important comments and additions to Jerphanion's work. ${ }^{5}$ She visited this location but was unable to get inside of Göreme 31, however, Pierre Lucas managed to take several photos inside the church in 2003. ${ }^{6}$ In 2014-2015 we were able to visit Göreme 31 and study the church in situ. In 2018 we visited it once again, verifying our previous results and checking the object state. ${ }^{7}$

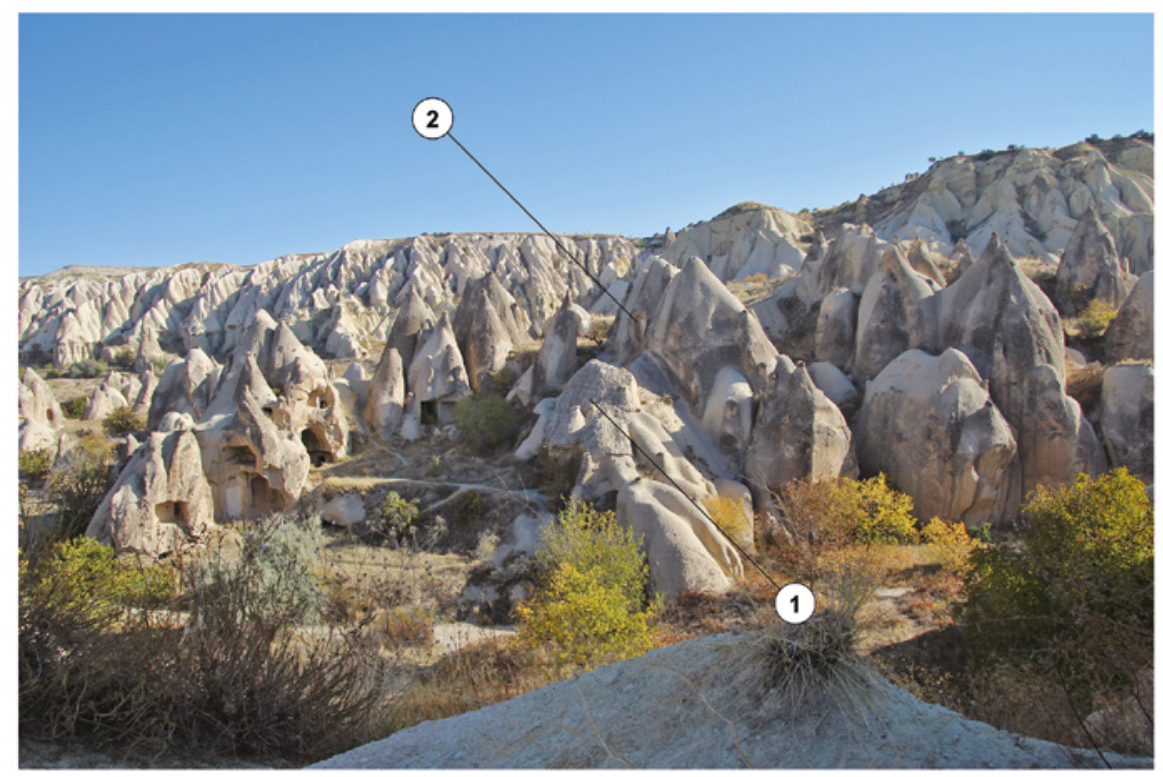

FIGURE 1 Göreme 31, the general view from outside. 1—the Kilıçlar church; 2-Göreme 31 PHOTO: YULIA SADOVSKAYA, NOVEMBER 2015

Well-preserved frescoes, most of which were published without photographs, as well as a few looted graves with human remains can be considered valuable scientific material. A systematic description of Göreme 31 is being prepared by the authors of this article and will be published later. ${ }^{8}$ In this article, we

4 GJ Texte I.1, pp. 254-258; GJ Planches I, pls. 54.2, 59.3, 59.4.

5 C. Jolivet-Lévy, La Cappadoce: un siècle après Guillaume de Jerphanion, Paris, 2015: Tome I, Texte; Tome II, Planches.

Further, for short, we refer to these volumes as CJL Tome I and CJL Tome II (respectively).

6 CJL Tome I, pp. 63-64; CJL Tome II, pls. 56-57.

7 The state of the object in 2018 was almost the same as in 2014-2015.

8 The full description of Göreme $3^{1}$ is to be published later in 2021-2022 as A. Ostrovsky, D. Shevchenko, Y. Sadovskaya, V. Shkondin, Göreme ${ }_{3}$ (Cappadocia, Turkey). 


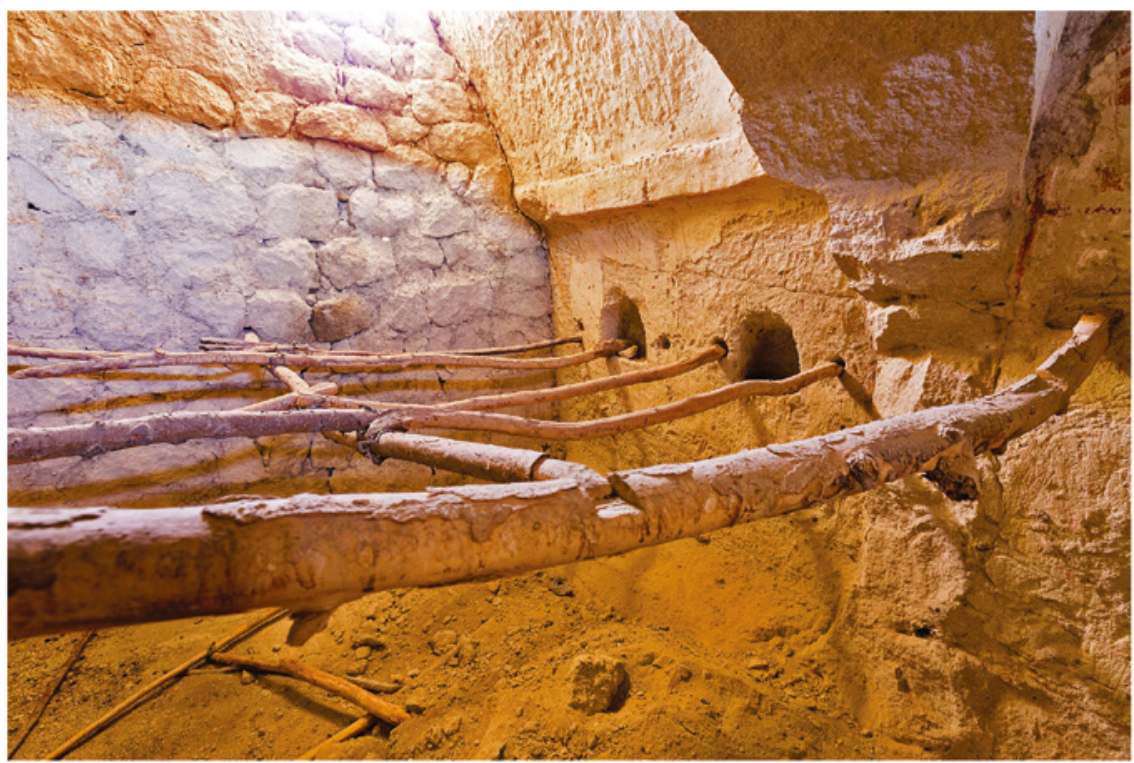

FIGURE 2 The naos, view from the narthex

PHOTO: VLADIMIR SHKONDIN, FEBRUARY 2017

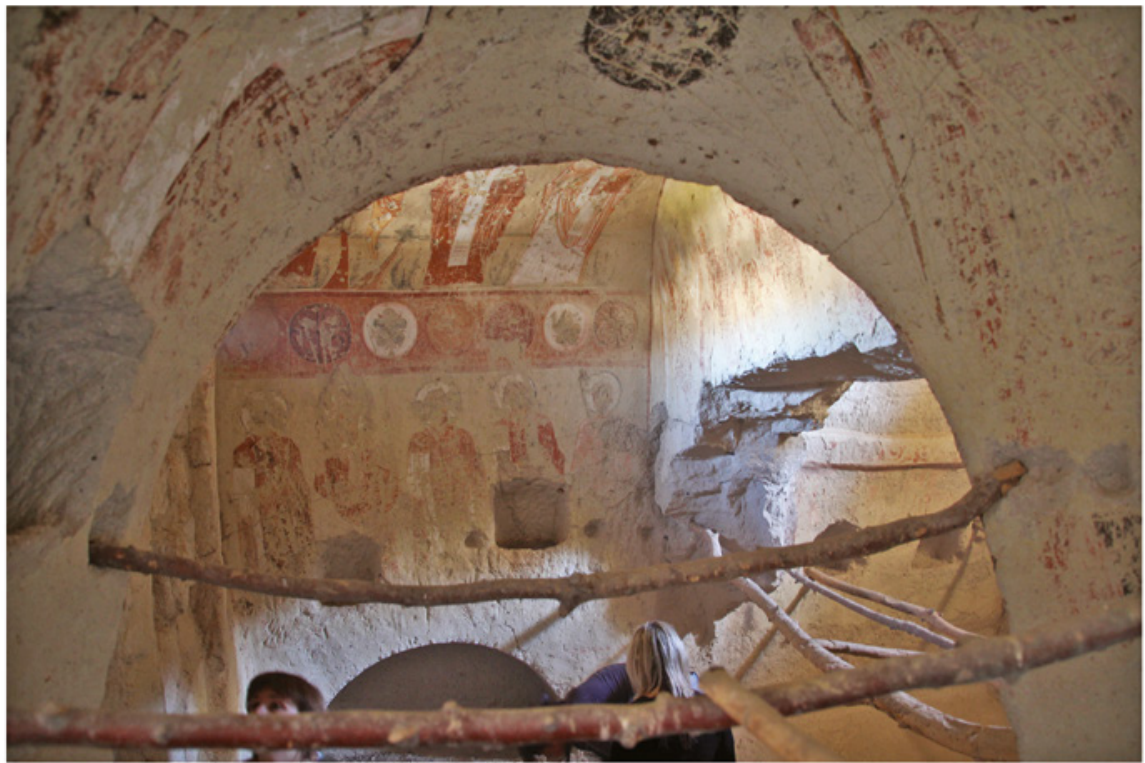

FIGURE 3 The narthex, view from the funeral chamber PHOTO: YULIA SADOVSKAYA, NOVEMBER 2015 


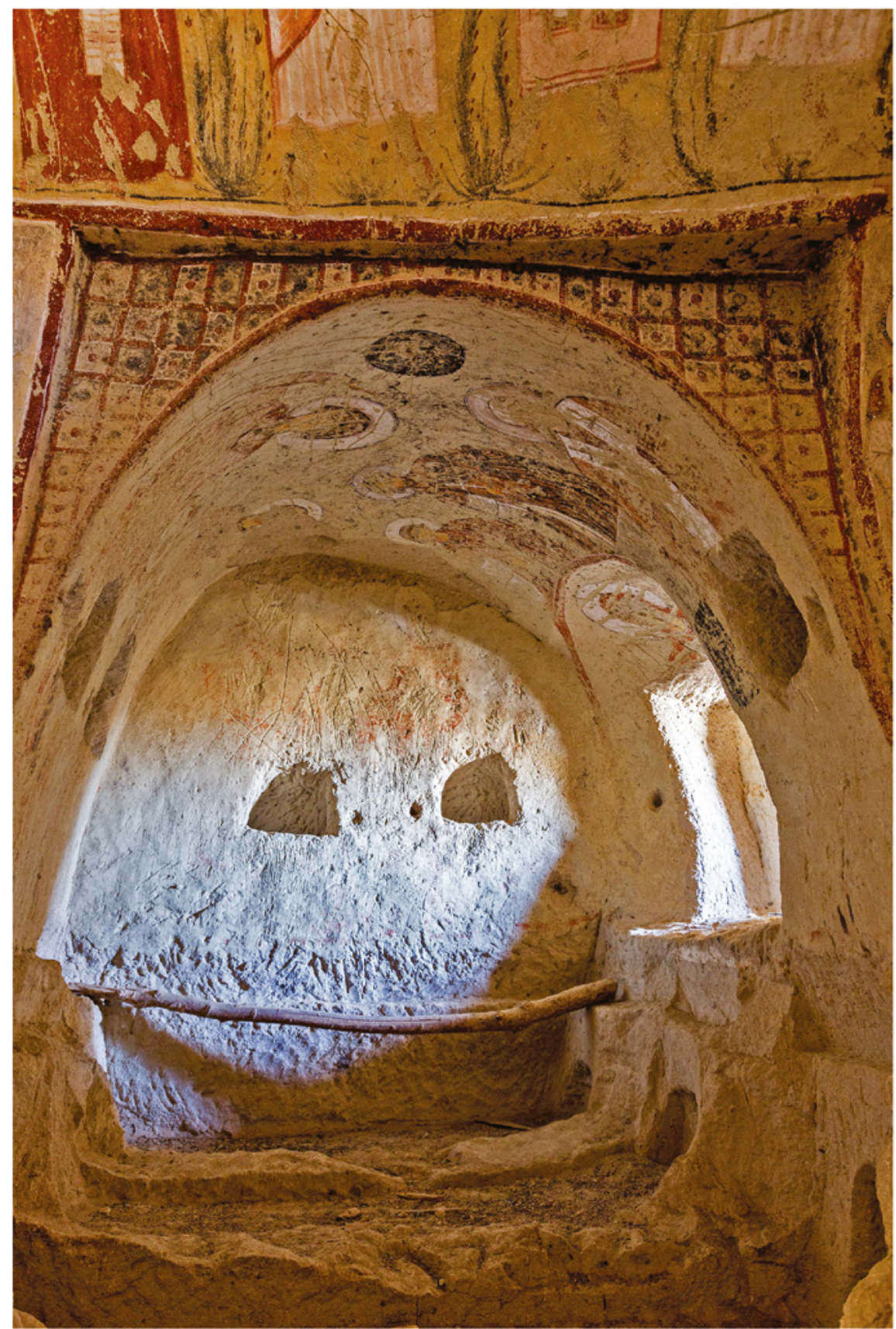

FIGURE 4 The funeral chamber, view from the narthex PHOTO: VLADIMIR SHKONDIN, FEBRUARY 2017 
present findings from our study, which are new compared to the published by previous researchers:

- necessary corrections to readings of frescoes, previously identified as St. Vincent, St. Irene, and St. George with St. Theodore;

- data on three new frescoes that were discovered in the naos;

- details on the enigmatic small grave in the funeral chamber.

Göreme $3^{1}$ is oriented along the East-West axis. Its internal space is divided into three areas - the naos, narthex, and funeral chamber that is attached to the narthex from the South (Figs. 2-4). ${ }^{9}$ The naos is poorly preserved. The eastern wall of the apse was destructed and the big passage that appeared as the result of destruction was bricked up with limestone slabs. The remnants of the destructed apse were revealed outside, several meters away to the East from the later limestone wall. The narthex and the funeral chamber are preserved much better.

Frescoes: Corrected Readings and New Findings

Forty frescoes are found in three rooms of the complex. The frescoes of the naos are in a bad state, while frescoes in the narthex and funeral chamber are preserved much better. As it was mentioned in the introduction, in the course of this article we limit ourselves only to the new findings from our study in situ, i.e. the corrected readings of the frescoes and brief description of three new frescoes, found in the naos.

\subsection{Naos: New Findings}

The naos was decorated with frescoes that now are almost destroyed. Remnants of several murals can be found on the northern and southern walls and the tympanum of the western wall. Three murals of the naos were not described earlier:

1) Remnants of one fresco can be found outside, in the former space of the apse that remained behind the wall of limestone slabs, built in the apse in 19th or 2oth century. Unfortunately, this fresco is almost totally destroyed and everything that can be told about it, is that probably it was a full-length figure of a saint.

9 Jerphanion attributed the funeral chamber as arcosolium (GJ Texte I.1, p. 257), but this is a separate room that was used as a funeral chamber. 


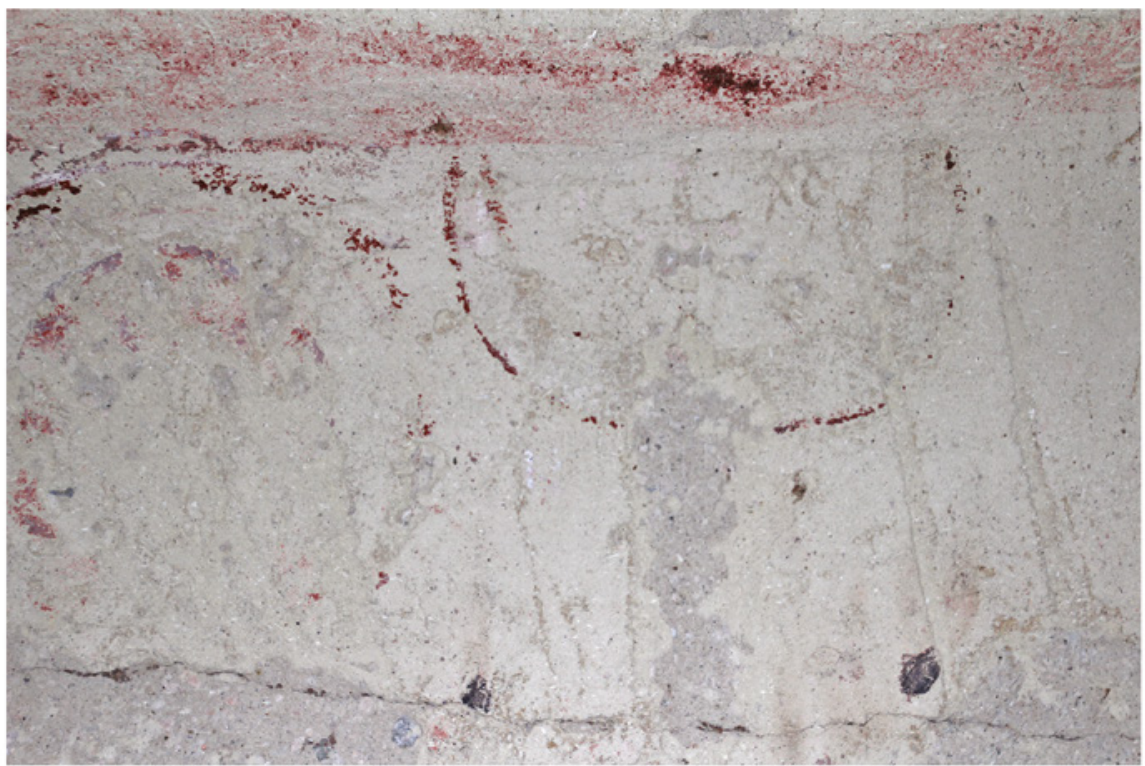

FIGURE 5 The naos, a fragment of the southern wall PHOTO: YULIA SADOVSKAYA, NOVEMBER 2015

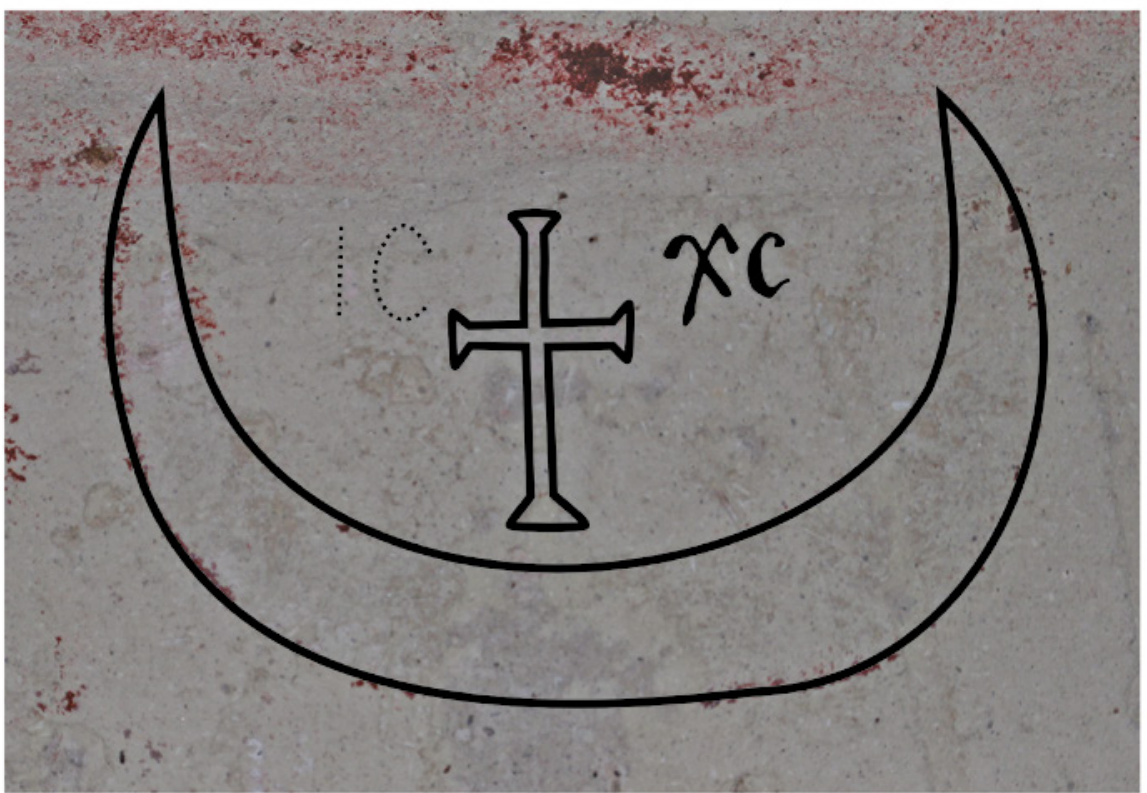

FIGURE 6 The naos, a crescent with a cross, drawing 
2) On the southern wall, closer to the apse, there are still visible remnants of another fresco. It is almost lost and all that remains is traces of a halo and minimal outlines of a slightly tilted head made in red paint. This allows us to make a tentative assumption that it may be remnants of a female figure in a maphorion (Fig. 5).

3) On the top right of the previous figure, there are hardly distinguishable traces of another image, which does not represent a saint. We can still identify a crescent with the ends pointed up, in the inner part of which there are visible traces of a cross and a horizontal inscription to both sides of the cross: $[\mathrm{IC}] \dagger \mathrm{XC}$ Jesus Christ (Fig. 6). This is the cross over crescent - an old Christian symbol connected with the Church and the idea of salvation within the Church.

\subsection{Naos: St. George and St. Theodore}

There are poorly distinguishable remains of two equestrian saints on the northern wall of the naos (Figs. 7, 8). Guillaume Jerphanion was unable to read the inscriptions and identify the saints. ${ }^{10}$ Catherine Jolivet-Lévy was also unable to read the inscriptions but tentatively assumed that the left saint (Fig. 7) might be St. George, and the right one (Fig. 8) - St. Theodore." This assumption is in line with the fact that St. Theodore on a red horse has parallels on frescoes in Cappadocia. After study in situ, we were able to identify both saints based directly on the fresco inscriptions.

The inscriptions are almost lost and to the right of the heads of both saints we have nothing but hardly distinguished remnants of several letters that can be roughly rendered as $[\ldots \cap--\cup \ldots]$ for the left one and as $\left[\Gamma^{\prime}-{ }_{--}{ }^{\prime} \cap\right]$ for the right one. As the equestrian saints have to be two of St. George, St. Theodore, and St. Demetrius, we select from a limited set of possible names for the saints: $\Gamma \Theta \omega P \Gamma I O C, \Theta \in O \triangle W P O C$, and $\triangle H M H T P I O C$. The right inscription cannot start with $\Theta$ or $\Delta$, therefore the only remaining possibility for it is $\left[\Gamma \epsilon_{---}-\mathrm{C}\right]$ for the name $\Gamma € \omega P \Gamma I O C$. Then, remnants of the left inscription can be interpreted as [-----P--O-] for the name $\triangle \mathrm{HMHTPIOC}$ (less likely), or [- $\left.\epsilon_{--} \omega_{---}\right]$for $\Theta \in O \triangle \omega P O C$ (more likely), but $\triangle$ HMHTPIOC must be excluded because there is no space for five letters $(\triangle \mathrm{HMHT}$ - or $\Delta$ IMIT-) between the halo and the visible fragment of the potential -P-. So, the only remaining possibility for the left fresco is St. Theodore with the inscription restored as $\left[\ldots \epsilon_{--} \omega_{\text {... }}\right]$ for the name $\Theta \in O \Delta \omega P O C .{ }^{12}$

\footnotetext{
$10 \quad$ GJ Texte I.1, p. 258.

11 CJL Tome I, p. 64.

$12 \operatorname{Or}[\ldots \in--\mathrm{O} \ldots .$.$] for \Theta \in O \triangle O P O C$ if there is an orthographical error.
} 


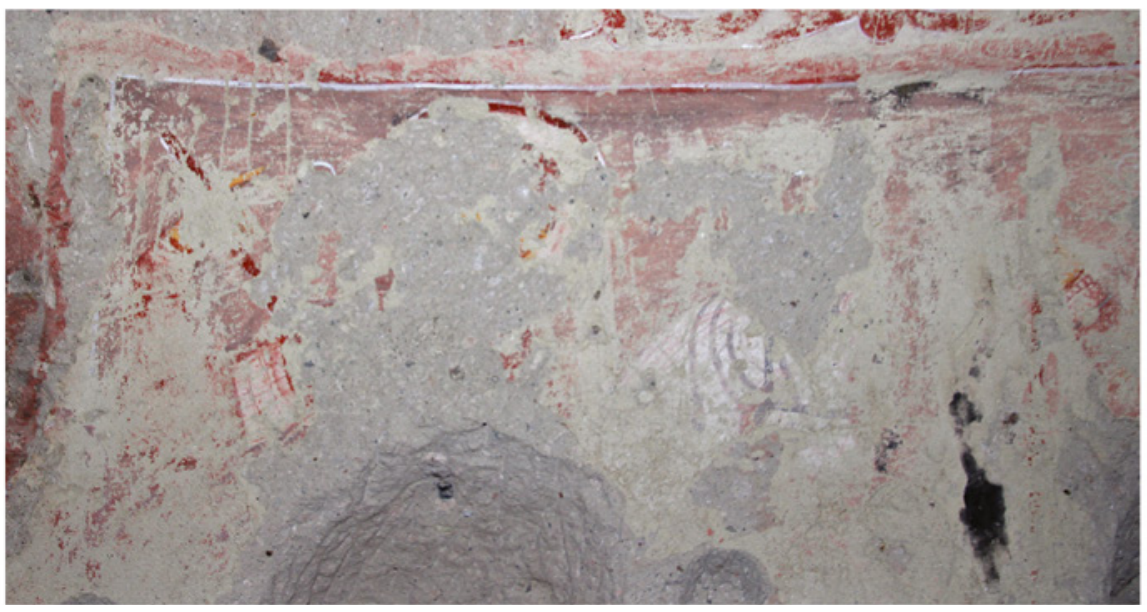

FIGURE 7 The naos, Saint Theodore

PHOTO: YULIA SADOVSKAYA, NOVEMBER 2015

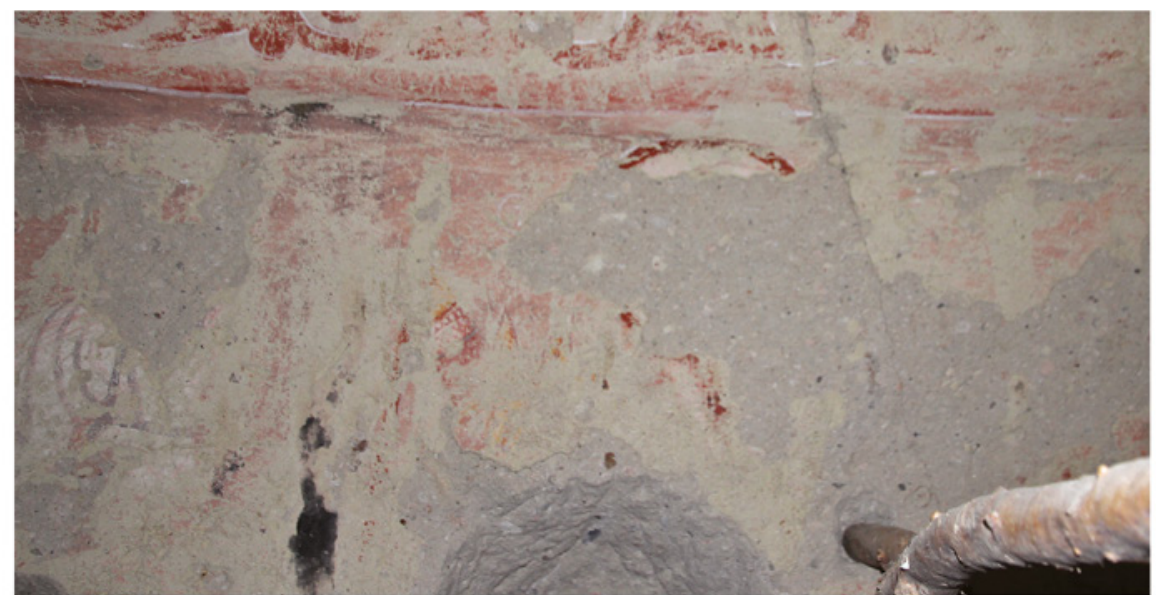

FIGURE 8 The naos, Saint George

PHOTO: YULIA SADOVSKAYA, NOVEMBER 2015

Therefore, the equestrian saints on the northern wall of the naos have to be identified as $[\Theta] \in[\mathrm{O} \Delta] \omega[\mathrm{POC}]$ Saint Theodore on the left (Fig. 7) and $\ulcorner €[\omega \mathrm{P} \Gamma] \mathrm{l}[\mathrm{O}] \mathrm{C}$ Saint George on the right, closer to the apse (Fig. 8). St.Theodore and St. George are riding towards each other, holding spears and pointing them down to the point between them. The horse of St. Theodore is definitely white, while the horse of St. George is either red or white, covered with a red blanket. 


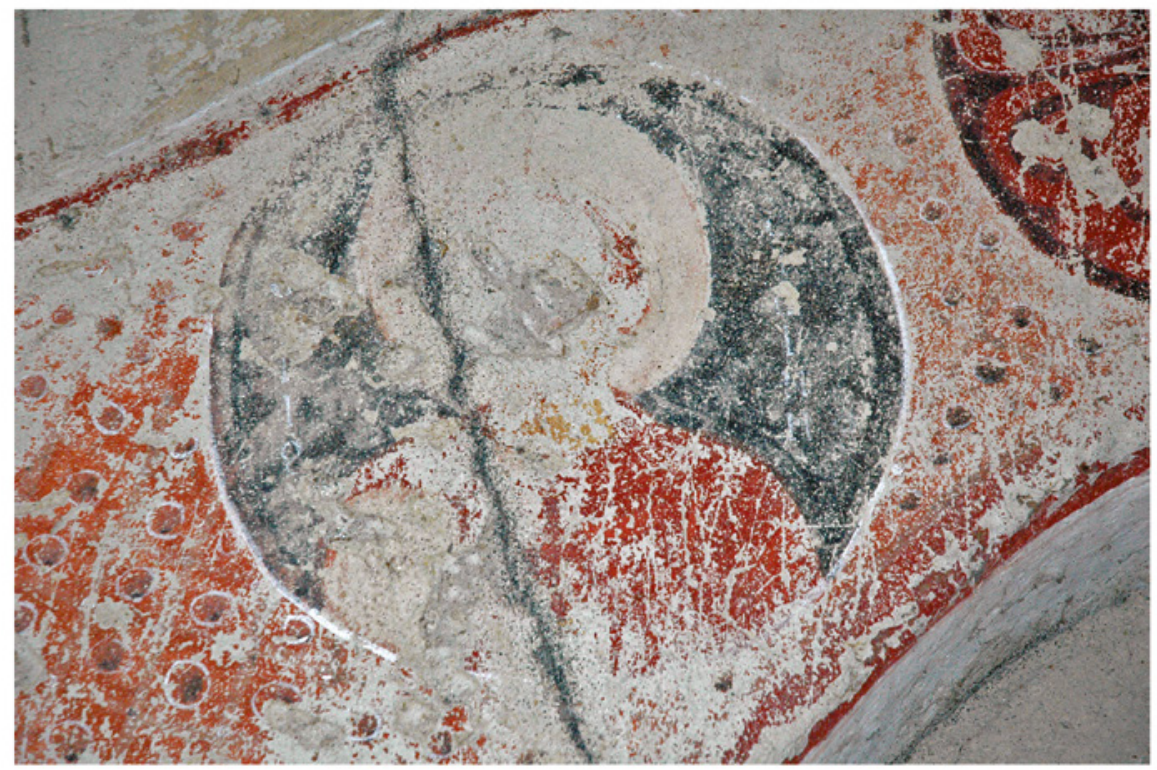

FIGURE 9 The narthex, Saint Sisinius

PHOTO: DANIL SHEVCHENKO, NOVEMBER 2015

Both saints are painted killing a serpent or a dragon, whose silhouette is barely distinguishable right below the horses' heads, between two saint warriors.

\subsection{Narthex: St. Sisinius (Previously Identified as St. Irene)}

The vault and all four walls of the narthex are decorated with frescoes and ornaments. Some of the frescoes of the narthex are damaged, but many of them are sufficiently preserved and still have readable inscriptions.

The leftmost medallion, located on the western wall of the narthex, above the main entry, has a grayish-black or dark blue background and contains a seriously damaged image of a saint in a red robe (Fig. 9). Guillaume Jerphanion read this inscription as $[\in I P] \mathrm{HNH}$ Irene, marking this reading as uncertain. ${ }^{13}$ Catherine Jolivet-Lévy marked this attribution as doubtful, and noticed that "le personnage en buste semble un jeune saint martyr, vêtu de la chlamyde". ${ }^{14}$

The actual reading of the fresco is $\mathrm{O}[\mathrm{A}] \Gamma \mathrm{IOC} \mathrm{CICINHOC}$ Saint Sisinius (Fig. 9).

\footnotetext{
13 GJTexte I.1, p. 257.

14 CJL Tome I, p. 64.
} 
The image corresponds to the iconographic guides for St. Sisinius that prescribe to draw him as an old man with a short and possibly round beard. ${ }^{15}$ We see several possibilities for attribution of this fresco: St. Sisinius, one of the Forty Martyrs of Sebaste (commemorated on March 9); St. Sisinius the Confessor, Bishop of Cyzicus (commemorated on September 23); and we cannot completely exclude Sisinnius I, archbishop of Constantinople (commemorated on October 11).

\subsection{Funeral Chamber: St. Auxentius (Previously Identified as St. Vincent)} The whole funeral chamber is decorated with paintings and contains nine frescoes with different levels of preservation.

The most prominent fresco of the funeral chamber is located on its western wall (Fig. 10). Guillaume Jerphanion initially proposed the reading (4) $[\mathrm{BI}] \mathrm{N}[\mathrm{K}] \in N T I O C$ St. Vincent and then asserted the correction (4) $[\mathrm{B}] \mathrm{H}[\mathrm{K}] \in \mathrm{NTIOC}$ St. Vincent. ${ }^{16}$ However, the researcher noticed that he used his photographs and records to provide this reading. ${ }^{17}$ Catherine Jolivet-Lévy sticks with the reading $[\mathrm{BI}] \mathrm{N}[\mathrm{K}] \in N T I O C$ as "the exact one". ${ }^{18}$ Therefore, both Jerphanion and Jolivet-Lévy read the inscription as St. Vincent.

Indeed, the top part of the inscription of the fresco is not visible quite well, but it still can be read: (4) AZENTIOC St. Auxentius (Fig. 10).

It seems like Guillaume Jerphanion misread the digraph $\mathrm{N}$ as $\mathrm{N}$ or $\mathrm{H}$. Also, even if one treats $A$ as $N$, there are no traces of letters $B I$ above $N$, and, actually, no space for them between the halo and $\mathrm{N}$ (counting that the inscription must be vertical). Anyway, all the letters are visible, and the reading St. Auxentius is doubtless.

Auxentius is painted as an older man with a beard and mustache, dressed in a pallium. In the left hand the saint holds a cross, a symbol of martyrs. The face of the saint is painted so thoroughly, that it is easy to recognize the small

15 See, for example, Дионисий Фурноаграфиот, Ерминия или наставление в живописном искусстве, составленное иермонахом и ивописцем Дионисием Фурноаграфиотом. 1701-1733 год, Киев, 1868 [Dionisius Fournoagrophiota, Herminia or guide in the art of painting, composed by hieromonk and artist Dionisius Fournoagrophiota. 1701-1733 year, Kiev, 1868]. This does not follow Jolivet-Lévy's view on "un jeune saint martyr", but on the new photographs we can clearly see an older man.

16 GJ Texte I.1, p. 257; idem, p. 257, fn. 4; GJ Texte I.2, p. 6o3.

17 GJ Texte I.1, p. 257, fns. 1, 4.

18 CJL Tome I, p. 64. Here we must mention once again, that Jolivet-Lévy was unable to examine the object in situ and used photographs to verify Jerphanion's data. 


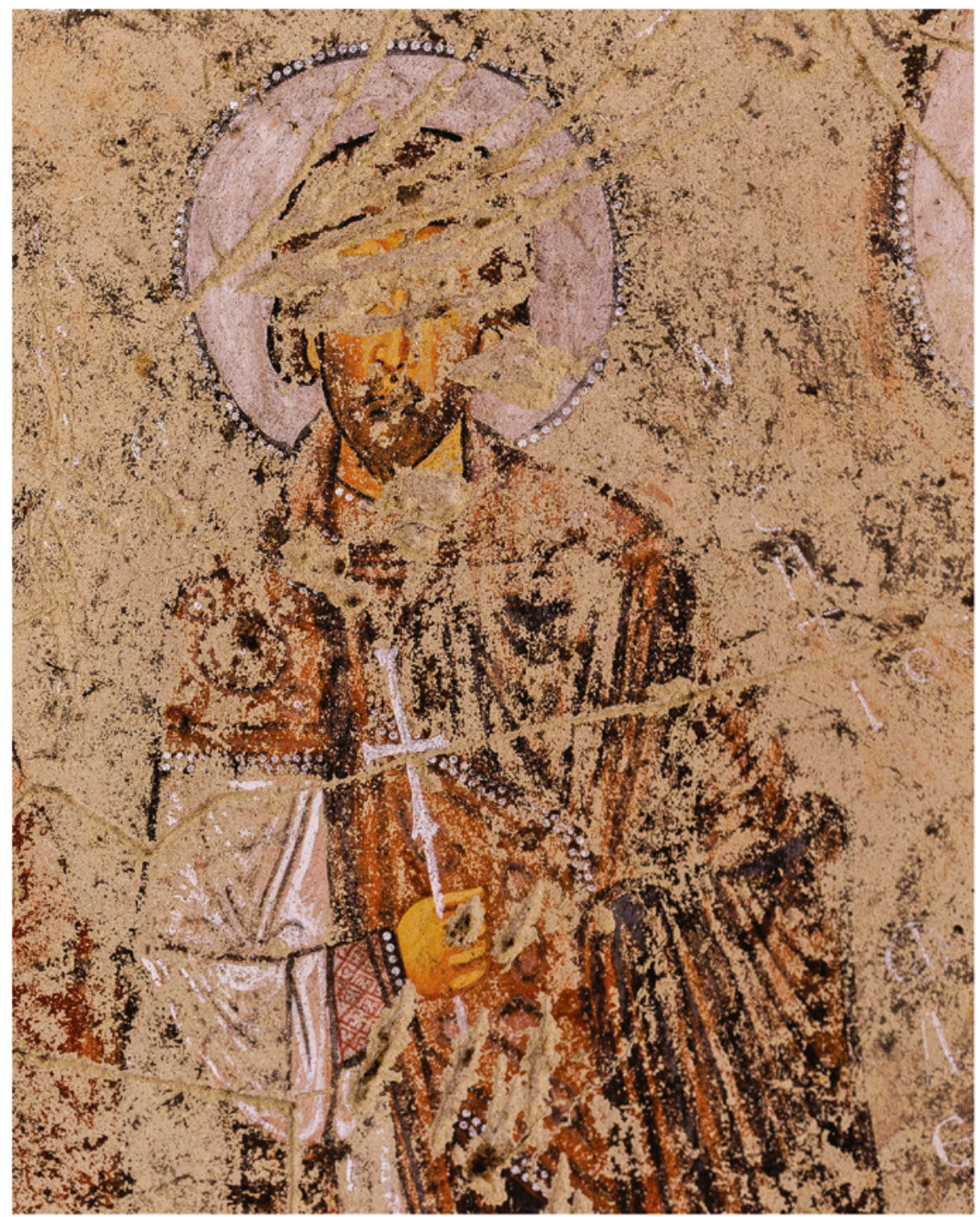

FIGURE 10 The funeral chamber, Saint Auxentius PHOTO: VLADIMIR SHKONDIN, FEBRUARY 2017

hairs of the mustache and beard. It surely indicates a high level of iconographer's skills.

Usually, the venerated saints with the name Auxentius are clerics. Taking into account the obvious laic status of St. Auxentius on the fresco, this may be Auxentius of Persia (commemorated on April 10), Auxentius of Sebaste (commemorated on December 13), or a local saint. 
Eleven graves are found in the narthex and the funeral chamber: four graves are located in the funeral chamber and seven more graves - in the narthex. All four graves in the funeral chamber were looted and no fragments of human bones remain in the room. Graves of the narthex were also excavated and looted but the room still contains multiple fragments of human bones and pieces of ceramics.

All the graves, except one, have the West-East orientation, which is typical for the Christian funeral tradition. One grave in the narthex is oriented with its head to the South, however, it cannot be considered as a violation of the funeral tradition: in some cases, the location of a grave depends on the limited internal space of the room.

A tiny burial pit is located in a niche separately from the other graves of the funeral chamber (Fig. 11). The pit is oriented over the line West-East, slightly expanding towards the West, and has unusually small dimensions of $30 \times 13 \times$ $12 \mathrm{~cm}$ (Fig. 12.a) - we do not recall burial pits of such a small size in Cappadocia. Unfortunately, the lack of osteological material does not allow us to make an unambiguous conclusion about its attribution.

Guillaume Jerphanion asserted that the pit is "une tombe d'enfant", without providing any details about the grave..$^{19}$ However, the size of the grave is not sufficient even for a newborn child. The typical length of a child's grave or even ossuary would be $60-70 \mathrm{~cm}$ (Fig. 12.b). We see three plausible versions of the possible purpose of such a small grave: it could belong to a premature (sic!) baby, or it could be an ossuary, intended for keeping holy relics, or it can be a cenotaph, intended for keeping personal items of the deceased. Let us consider each of these versions.

1) A grave of a premature baby. As it was mentioned above, the dimensions of the pit are $30 \times 13 \times 12 \mathrm{~cm}$, which complies with the maximum fetal age around $20-21$ weeks when the average fetus is $25 \cdot 5^{-27.2 ~} \mathrm{~cm}$ long. ${ }^{20} \mathrm{So}$, the grave could be made for a body of the maximum fetal age of $20-21$ weeks, which is an edge between a miscarried fetus and a premature baby. It is extremely unlikely that such a young preemie could survive even for a short time in the Middle Ages. If we assume, as an extraordinary assumption, that a newborn had received the baptism immediately after a preterm birth (or miscarriage, as it is 2oth-21st

\footnotetext{
19 GJ Texte I.1, p. 257. Other researchers do not discuss this grave.

20 M.A. Curran. Fetal Development (reviewed March 31, 2019). Available online at http:// perinatology.com/Reference/Fetal\%2odevelopment.htm (Accessed: 1 Sep 2020).
} 


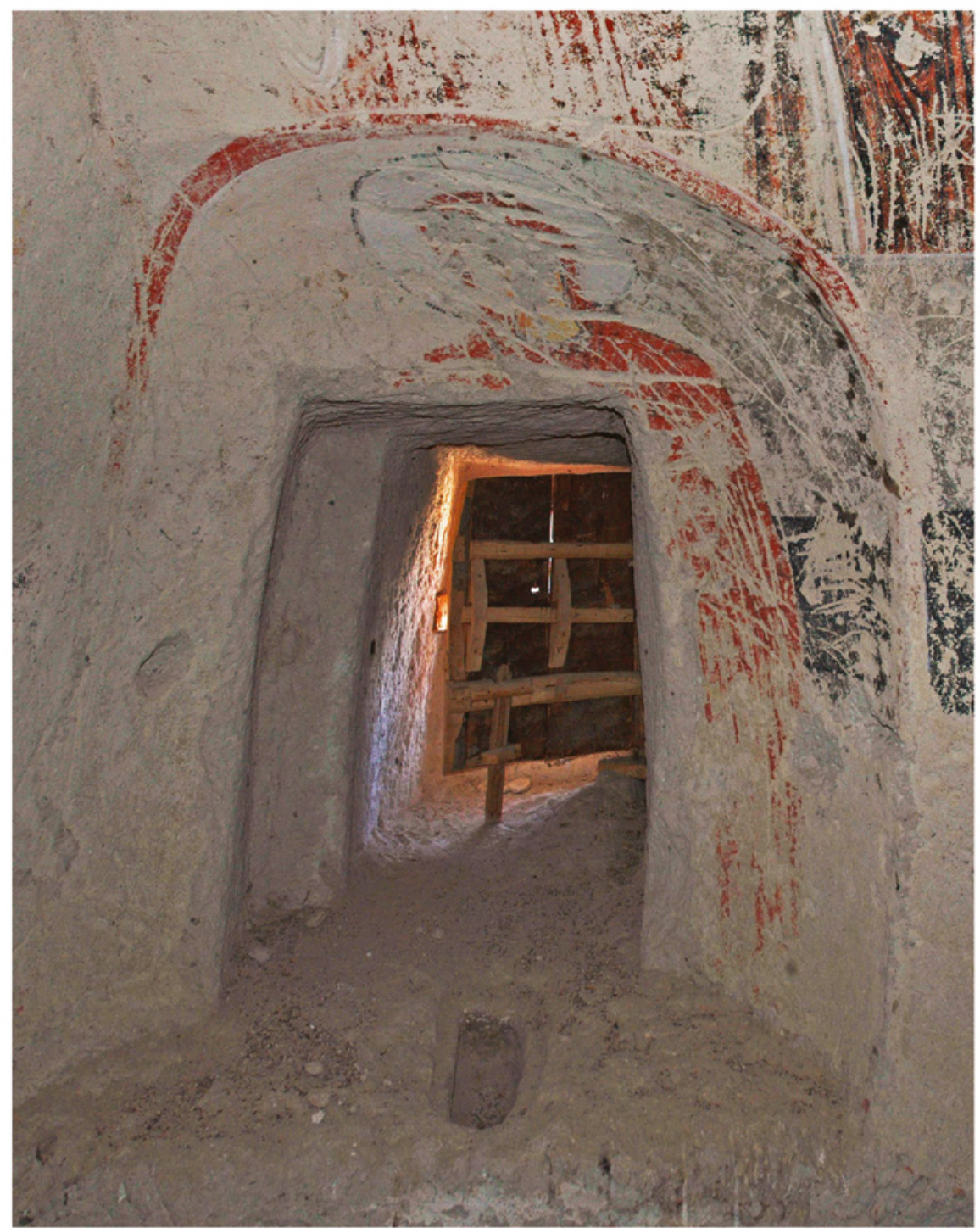

FIGURE 11 The funeral chamber, a niche in the western wall PHOTO: DANIL SHEVCHENKO, NOVEMBER 2015

week) and died soon after that, theoretically, it could be buried in the funeral chamber within the church space. However, the question of how realistic was baptizing of a 21-week old preemie remains open and we are quite skeptical about that possibility.

2) An ossuary. Burying holy relics or partial remnants was a widespread funeral practice in the region, but usually, an ossuary was much bigger and 

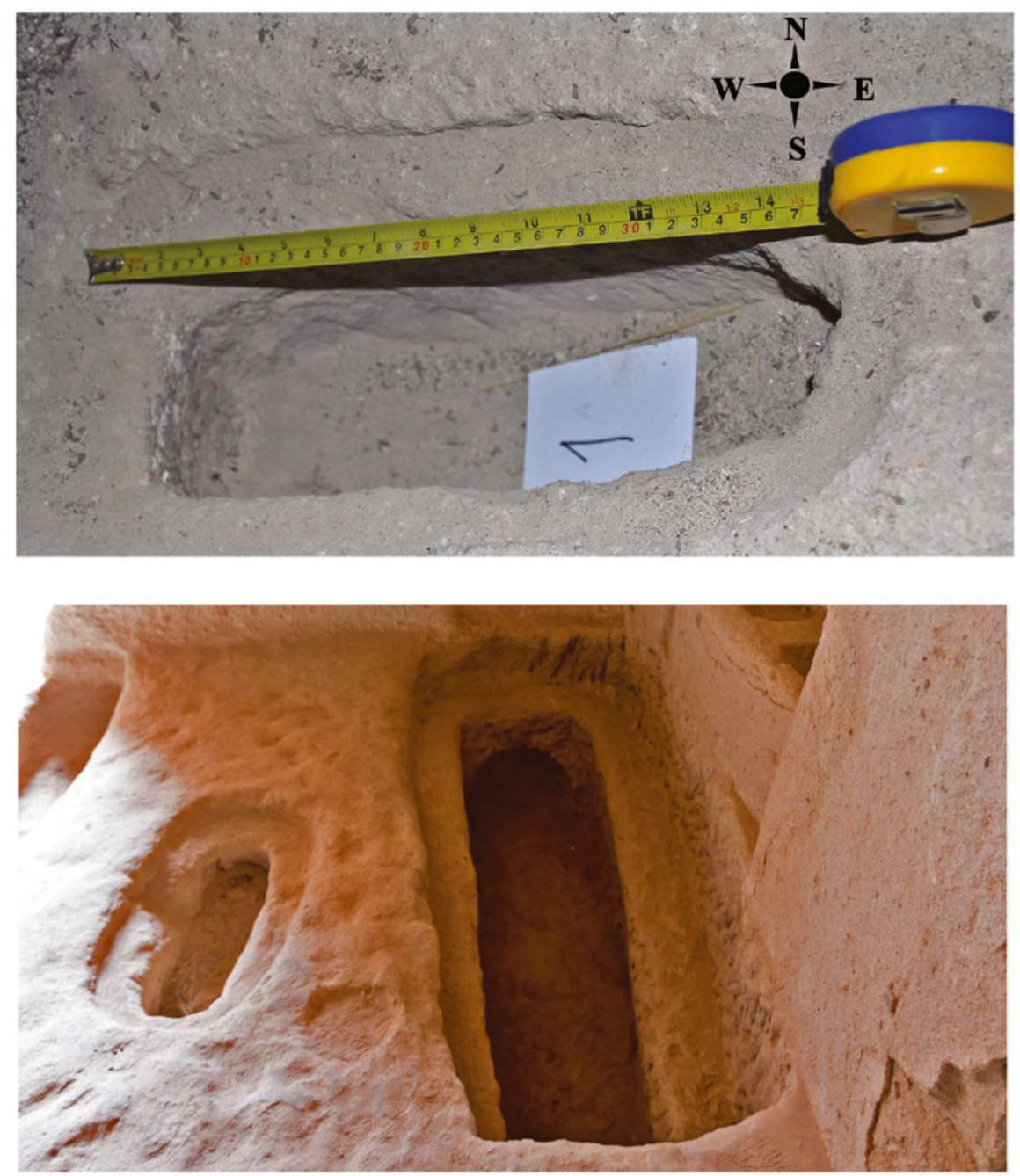

FIGURE 12 a) Upper: The tiny grave in the funeral chamber PHOTO: YULIA SADOVSKAYA, NOVEMBER 2015

b) Lower: Example of a typical ossuary in Cappadocia. Zelve Open Air Museum, near coordinates $38^{\circ} 40^{\prime}$ oo. $7^{\prime \prime} \mathrm{N}, 34^{\circ} 51^{\prime} 55.0^{\prime \prime} \mathrm{E}$

PHOTO: VLADIMIR SHKONDIN, FEBRUARY 2019

deeper. However, if the relics belonged to a child, the size of the pit would be enough for both bones and cranium, and in this case, we are not limited to a premature age with the size of a buried body. Usually, the orientation of an ossuary does not strictly comply with the cardinal directions and it may have one of two shapes - a rectangle with rounded corners and an oval (Fig. 12.b).

3) A cenotaph. This burial practice is rooted in the Neolithic tradition when for some reason a human body could be unavailable for inhumation, but a 
community needed to make a grave for commemoration to preserve the collective memory. In this case, a community can make a cenotaph - a grave containing personal items of the deceased, or other artifacts that had to remind about that person. The tradition of cenotaphs was common for a long time up to the late Roman period, and it was not completely abandoned after the fall of the Roman Empire.

We do not insist on any of the versions described above, although we tentatively note that the small size of the grave, its somewhat free orientation (a little misalignment compared to the other graves), and the presence of a fresco of St. Anne, who is a patroness of pregnant women and newborns, may allow one to assume that an ossuary of a child may be more plausible than two other versions.

\section{Conclusion and the Research Perspectives}

Based on the paleographic features of epigraphic material, we assume that the church can be broadly dated to the period of the seventh-eleventh centuries with the most probable dating not going before the ninth century. The approximate dating, that is based on the iconographical analogies and artistic features of the frescoes, attributes the church to the tenth-eleventh centuries. Thus, we preliminarily date Göreme 31 to the period of the tenth-eleventh centuries. We will return to the question of dating of this church in our detailed report (to be published later).

Further paleographic and archeological research is required and may clarify or correct the preliminary dating of the church. Because of the dedicated status of the funeral chamber of Göreme 31, research of the osteological material can be especially informative. It may provide us with various information from the radiocarbon dating of the graves to the ethnic affiliation and kinship ties of the buried people based on the DNA tests. Furthermore, the analysis of the ceramics and other funeral items, which probably are preserved in some graves, will reveal the social status of the family. Therefore, in the case of the archaeological excavations, findings from Göreme 31 may shed some light on the ethnic and social structure of the region in the Middle Ages.

\section{Acknowledgement}

We would like to express our deep gratitude to Prof. Robert G. Ousterhout (University of Pennsylvania, USA), Dragan Jacanović (Narodni Muzej Požarevac, Serbia), Gamze Pişkiner (Istanbul Museum of Modern Art, Turkey), Denis 
Beletskiy (Moscow, Russia), Yulia Smolyanka (Irkutsk, Russia), and Natalia Smelova and Nikolay Chicherin-Lipatov (UK) for useful advices during work on this article.

We also commend Elena Grudtsyna (Russia), John Clark (Shenyang, China), Lukasz Oleszczak (Kraków, Poland), Mehmet Kececi (Nevşehir, Turkey), Anastasia Demidova (France) and Valentina Kalmutskaya (Russia) for their kind help and support.

Last, but not least, once again we would like to thank mountain-climbers Vsevolod Mamontov and Justina Kvrivishvili (Saint Petersburg, Russia), without their curiosity this work could not be possible. 